\title{
RFWD3 wt Allele
}

National Cancer Institute

\section{Source}

National Cancer Institute. RFWD3 wt Allele. NCI Thesaurus. Code C138091.

Human RFWD3 wild-type allele is located in the vicinity of $16 q 23.1$ and is approximately $45 \mathrm{~kb}$ in length. This allele, which encodes E3 ubiquitin-protein ligase RFWD3 protein, plays a role in the modulation of the DNA damage checkpoint of the cell cycle. Biallelic mutations in the gene are associated with Fanconi anemia. 